\title{
DETERMINAN AKUNTABILITAS KINERJA PEMERINTAH DI KABUPATEN LOMBOK BARAT
}

\author{
Andi Permana Putra \\ ansel_king@yahoo.com \\ BAPPEDA Kabupaten Lombok Barat \\ Akram \\ Hermanto \\ Program Magister Akuntansi Universitas Mataram
}

\begin{abstract}
The purpose of this study is to analyze and prove the factors that affect the accountability of government performance in financial management, especially in West Lombok regency. Issues of accountability are phenomena and have always been the spotlight in the community, especially the low quality of government agencies' performance in managing local finances that often have an impact on the abuse of authority. Factors that degrade the quality of accountability to the local government is the lack of budget targeting and reporting. Besides it is still less than optimal implementation of performance-based budgeting and internal controls over financial management. This research is an explanatory research. The data in this study are primary data collected using questionnaires. The total sample is 87 regional finance management officials determined using disproportional stratified random sampling technique. Data analysis used in this research is multiple linear regression analysis. This study proves that the implementation of performance-based budgeting, internal control, clarity of budget targets and reporting have a positive effect on the performance accountability of local government financial management.
\end{abstract}

Key words: budgeting; internal control; goal clarity; reporting; performance accountability

\begin{abstract}
ABSTRAK
Tujuan penelitian ini adalah untuk menganalisis dan membuktikan faktor-faktor yang mempengaruhi akuntabilitas kinerja pemerintah pada pengelolaan keuangan khususnya di Kabupaten Lombok Barat. Permasalahan akuntabilitas merupakan fenomena dan selalu menjadi sorotan di masyarakat terutama rendahnya kualitas kinerja instansi pemerintah dalam mengelola keuangan daerah yang sering berdampak pada penyalahgunaan wewenang. Faktor-faktor yang menurunkan kualitas pertanggungjawaban pada pemerintah daerah adalah lemahnya penetapan sasaran anggaran dan pelaporan yang dilakukan. Selain itu masih kurang optimalnya penerapan penganggaran berbasis kinerja serta pengendalian internal pada pengelolaan keuangan daerah. Penelitian ini merupakan penelitian eksplanatori. Data pada penelitian ini adalah data primer yang dikumpulkan menggunakan kuesioner. Total sampel adalah sebanyak 87 pejabat pengelola keuangan daerah yang ditentukan menggunakan tekhnik disproporsional stratified random sampling. Analisis data yang digunakan pada penelitian ini adalah analisis regresi linier berganda. Penelitian ini membuktikan bahwa implementasi penganggaran berbasis kinerja, pengendalian internal, kejelasan sasaran anggaran dan pelaporan berpengaruh positif terhadap akuntabilitas kinerja pengelolaan keuangan pemerintah daerah.
\end{abstract}

Kata kunci: penganggaran, pengendalian internal, kejelasan sasaran, pelaporan, akuntabilitas kinerja

\section{PENDAHULUAN}

Tata kelola pemerintahan yang baik dibutuhkan pada suatu penyelenggaraan otonomi daerah yang diwujudkan melalui pengembangan dan penerapan sistem pertanggungjawaban pemerintah yang akun- 
tabel dan transparan. Pertanggungjawaban atau akuntabilitas pemerintahan diwujudkan ke dalam LAKIP atau Laporan Akuntabilitas Kinerja Instansi Pemerintah yang menggambarkan pertanggungjawaban pemerintah kepada publik tentang kinerja melalui pengelolaan keuangan selama satu tahun anggaran. Pengelolaan keuangan pada penyelenggaraan pemerintahan yang akuntabel akan mendapat dukungan dan kepercayaan dari publik atas apa yang diselenggarakan, direncanakan, dan dilaksanakan oleh program yang berorientasi kepada publik, sementara itu di pihak penyelenggara akuntabilitas mencerminkan komitmen pemerintah dalam melayani publik. Berdasarkan Inpres Nomor 7 Tahun 1999, akuntabilitas kinerja instansi peme rintah didefinisikan sebagai perwujudan kewajiban instansi pemerintah untuk mem pertanggungjawabkan keberhasilan pelaksanaan visi dan misi organisasi dalam mencapai tujuan dan sasaran yang telah ditetapkan secara periodik. Akuntabilitas kinerja pada pengelolaan keuangan adalah bentuk pertanggungjawaban sekaligus evaluasi diri dalam rangka peningkatan kinerja. Peningkatan akuntabilitas kinerja pemerintah daerah dapat diwujudkan melalui penganggaran berbasis kinerja, pengendalian internal yang memenuhi prinsip value for money, kejelasan sasaran anggaran dan memperhatikan pelaporan yang baik dan tepat. Permasalahan yang sering ditemukan pada pemerintah daerah adalah masih ditemukannya ketidakselarasan antara perencanaan dan penganggaran serta rendahnya pengawasan kinerja terhadap indikator yang ditunjukkan dengan capaian kinerja tidak sesuai dengan target yang ditetapkan dengan demikian akuntabilitas kinerja pemerintah daerah masih perlu dibenahi karena sesungguhnya otonomi daerah harus dapat mencerminkan adanya keterbukaan dalam hal penyelenggaraan pemerintahan dan pengelolaan keuangan publik. Permasalahan akuntabilitas pada pemerintah daerah berhubungan terhadap administrative accountability dan professional accountability yakni menonjolkan isu-isu yang berkaitan dengan buruknya kinerja pengelolaan keuangan daerah, layaknya yang terjadi di Kabupaten Lombok Barat yakni diindikasikan melalui opini WTP BPK yang belum tercapai selama kurun waktu 2008-2013, nilai LAKIP selama kurun waktu 4 tahun terakhir yakni nilai $C$ serta masih adanya terjadinya kejadian korupsi pada lingkup pemerintah daerah seperti penyalah gunaan wewenang dan suap, oleh karena itu penelitian terkait akuntabilitas kinerja pada pemerintah daerah menarik untuk dijadikan penelitian. Halim (2004) dalam Yani (2014) menyatakan akuntabilitas publik adalah pemberian informasi dan pengungkapan atas aktivitas dan kinerja keuangan pemerintah kepada pihak-pihak yang berkepentingan. Pendapat tersebut sejalan Teori Keagenan (Agency Theory) yang menggambarkan hubungan kontraktual antara agen dan prinsipal yakni antara masyarakat sebagai pemberi amanah dan pemerintah daerah sebagai penerima amanah/pengelola, dimana pengelola berkewajiban untuk mempertanggungjawabkan kepada masyarakat pengelolaan yang diamanahkan. Halim dan Abdullah (2006) menyimpulkan bahwa masalah keagenan di pemerintahan daerah bagian tidak terpisahkan dalam penelitian akuntansi sektor publik, dimana eksekutif merupakan agen bagi legislatif dan publik (dual accountability) dan legislatif merupakan agen bagi publik. Selanjutnya dijelaskan bahwa konsep perwakilan (representativeness) tidak sepenuhnya dapat berjalan ketika kepentingan publik tidak menjadi prioritas oleh karena adanya perilaku oportunistik legislatif. Sementara itu, eksekutif sebagai agen cenderung menjadi budget maximizer karena berperilaku adverse selecation sekaligus moral hazard. Pengelolaan keuangan pada lingkup pemerintah daerah mutlak memerlukan pertanggungjawaban, hal ini berkaitan dengan fungsi pemerintah dalam memberikan pelayanan kepada masyarakat. Akuntabilitas kinerja pemerintah daerah dapat dinilai baik jika dilaksanakan sesuai aturan yang telah 
ditetapkan secara baik dan benar, dalam hal ini suatu akuntabilitas dapat dicapai dengan optimal melalui implementasi penganggaran berbasis kinerja sesuai prosedur yang baik tentu saja akan memenuhi kaidah akuntabilitas yakni efektif dan efisien, selain itu juga dengan penerapan sistem pengendalian internal yang baik maka sasaran dari penggunaan keuangan daerah dapat dipertanggungjawabkan dan dapat lebih sesuai sasaran dan tujuan. Berdasarkan datadata yang tersedia menunjukkan fenomena rendahnya kualitas pertanggungjawaban masih terjadi pada lingkup pemerintah daerah, dimana fakta tersebut akan membuka kemungkinan terjadinya penyelewengan dan tindakan negatif lainnya. Oleh karena itu penelitian ini bertujuan untuk menganalisis dan membuktikan pengaruh implementasi penganggaran berbasis kinerja, pengendalian internal, kejelasan sasaran anggaran dan pelaporan dalam memengaruhi akuntabilitas kinerja pengelolaan keuangan pemerintah daerah.

\section{TINJAUAN TEORETIS}

\section{Teori Keagenan (Agency Theory)}

Teori keagenan menjelaskan bahwa hubungan agensi muncul ketika satu orang atau lebih (principals) mempekerjakan orang lain (agent) untuk memberikan suatu jasa dan kemudian mendelegasikan wewenang pengambilan keputusan kepada agen tersebut (Jensen dan Meckling, 1976). Teori keagenan akan berlaku pada berbagai organisasi termasuk pada organisasi sektor publik yakni pemerintah daerah dan berfokus pada persoalan asimetri informasi yang terjadi antara eksekutif selaku pengelola (agent) dan masyarakat (principals).

Akuntabilitas dapat dipahami sebagai kewajiban pihak pemegang amanah (agent) dalam memberikan pertanggungjawaban, menyajikan, melaporkan, dan mengungkapkan segala aktivitas dan kegiatan yang menjadi tanggung jawabnya kepada pihak pemberi amanah (principals) yang memiliki hak dan kewenangan untuk meminta pertanggungjawaban tersebut (Mardiasmo,
2002), oleh karena itu akuntabilitas dapat dijelaskan menggunakan teori keagenan karena dapat menjelaskan hubungan kontraktual antara pemberi amanah (principals) dan pemegang amanah (agent).

\section{Pengelolaan Keuangan Daerah}

Undang-undang Nomor 1 Tahun 2004 mengatur bagaimana pengelolaan keuangan yang terdiri dari perencanaan, pelaksanaan, dan pemeriksaan keuangan publik (negara dan daerah) dilaksanakan oleh pemerintah. Pengelolaan Keuangan Daerah adalah keseluruhan kegiatan pejabat pengelola keuangan daerah sesuai dengan kedudukan dan kewenangannya, yang meliputi perencanaan, pelaksanaan, pengawasan, dan pertanggungjawaban (Undang-undang Nomor 15 Tahun 2004). Definisi tersebut diatas mencerminkan bahwa berbicara pengelolaan keuangan daerah berarti membahas kedudukan dan kewenangan dari orang-orang yang menangani keuangan daerah, yang kemudian disebut pejabat pengelola keuangan daerah yang memiliki tugas dan fungsi mengatur tentang keuangan daerah. Berdasarkan Peraturan Peme- rintah Nomor 58 tahun 2005 Pengelolaan Keuangan Daerah didefinisikan sebagai keseluruhan kegiatan yang meliputi perencanaan, pelaksanaan, penatausahaan, pelaporan, pertanggungjawaban, dan pengawasan keuangan daerah. Pengelolaan keuangan daerah harus dikelola secara tertib, taat pada peraturan perundang-undangan, efektif, efisien, ekonomis, transparan, dan bertanggung jawab dengan memperhatikan azas keadilan, kepatutan, dan manfaat untuk masyarakat. Proses Pengelolaaan keuangan daerah dimulai dengan perencanaan/penyusunan anggaran pendapatan belanja daerah (AP$B D)$, dimana APBD disusun berpedoman kepada RKPD dalam rangka mewujudkan pelayanan kepada masyarakat untuk tercapainya tujuan bernegara.

\section{Akuntabilitas Kinerja Pemerintah Daerah}

Mardiasmo (2002) menyebutkan bahwa akuntabilitas dapat dipahami sebagai 
kewajiban pihak pemegang amanah (agent) untuk memberikan pertanggungjawaban, menyajikan, melaporkan dan mengungkapkan segala aktivitas dan kegiatan yang menjadi tanggung jawabnya kepada pihak pemberi amanah (principals) yang memiliki hak dan kewenangan untuk meminta pertanggungjawaban tersebut. Akuntabilitas adalah suatu keharusan bagi lembaga sektor publik untuk lebih menekankan pada tanggungjawab horizontal (masyarakat) dan bukan hanya tanggungjawab vertikal. Berdasarkan Peraturan Presiden Nomor 29 Tahun 2014 disebutkan bahwa akuntabilitas kinerja pemerintah daerah merupakan perwujudan kewajiban suatu instansi pemerintah untuk mempertanggung-jawabkan keberhasilan atau kegagalan pelaksanaan misi organisasi dalam mencapai sasaran dan tujuan yang telah ditetapkan melalui sistem pertanggungjawaban secara periodik. Dengan demikian akuntabilitas kinerja pemerintah daerah dapat disimpulkan sebagai kemampuan memberikan jawaban atas pelaksanaan kegiatan organisasi sebagai bahan evaluasi bagi otoritas yang lebih tinggi dan juga masyarakat serta sebagai umpan balik untuk meningkatkan kinerja organisasi pada masa yang akan datang.

\section{Penganggaran Berbasis Kinerja}

Penganggaran berbasis kinerja adalah sistem yang mencakup kegiatan penyusunan dan tolok ukur kinerja sebagai instrumen untuk mencapai tujuan dan sasaran program (Mardiasmo, 2009:84). Implementasi penganggaran berbasis kinerja diatur dalam Peraturan Menteri Dalam Negeri Nomor 13 Tahun 2006 sebagaimana telah diubah lagi dengan Peraturan Menteri Dalam Negeri Nomor 21 Tahun 2011 yang merupakan salah satu bentuk upaya proses perbaikan penyusunan anggaran untuk menciptakan transaparansi dan meningkatkan akuntabilitas kinerja pemerintah daerah.

Bastian (2006) menjelaskan sistem penganggaran adalah berorientasi "output" dan berkaitan dengan visi dan misi organisasi, dengan demikian pengukuran "output" oleh organisasi adalah sebagai indikator kinerja yang dilakukan dalam mengalokasikan sumber daya pada program. Oleh karena itu, penganggaran berbasis kinerja dapat disimpulkan sebagai penganggaran yang disusun secara jelas dan sistematis menggunakan indikator kinerja dengan konsep value for money sehingga implementasinya dapat dicapai secara ekonomis, efektif dan efisien serta dapat dievaluasi secara periodik.

\section{Pengendalian Internal}

Pengendalian dapat diartikan sebagai suatu sistem dan prosedur yang secara otomatis dapat saling memeriksa, dalam arti bahwa data akuntasi yang dihasilkan suatu bagian atau fungsi secara otomatis dapat diperiksa oleh bagian atau fungsi lain dalam suatu usaha (Damayanti, 2017). Pengendalian internal meliputi struktur organisasi, metode dan ukuran-ukuran yang dikoordinasikan untuk menjaga kekayaan organisasi, mengecek ketelitian dan keandalan data akuntansi, mendorong efisiensi dan mendorong dipatuhinya kebijaksanaan manajemen. Penerapan pengendalian internal yang baik berarti bahwa pengelolaan keuangan yang dilaksanakan instansi pemerintah daerah melalui kegiatan-kegiatan oleh seluruh pimpinan dapat dipertanggungjawabkan dan transparan, hal ini berarti bahwa pengendalian internal yang diterapkan dengan baik dapat meningkatkan akuntabilitas kinerja yang mencakup tuntutan dan harapan agar aparat pemerintah mampu menciptakan birokrasi yang kuat dalam mencapai tujuan yang menjadi cita-cita.

\section{Kejelasan Sasaran Anggaran}

Hidayatullah dan Herdjiono (2015) menyatakan bahwa pemerintah selaku pengelola dana publik agar dapat memenuhi akuntabilitas kiranya memperhatikan beberapa hal diantaranya adalah anggaran yang memiliki ciri yakni kejelasan sasaran anggaran, dimana kejelasan sasaran anggaran dapat memudahkan penyusunan target-target anggaran yang sesuai. Pe- 
ngelolaan keuangan pemerintahan daerah yang berakuntabilitas tidak lepas dari anggaran pemerintah daerah yang digunakan dalam pengelolaan sumber daya dengan baik untuk mencapai kinerja yang menjadi tujuan. Suhartono dan Solichin (2006) menjelaskan bahwa kejelasan sasaran anggaran merupakan sejauh mana tujuan anggaran ditetapkan secara jelas dan spesifik dengan tujuan agar anggaran tersebut dapat dimengerti oleh orang yang bertanggungjawab atas pencapaian sasaran anggaran tersebut. Kejelasan sasaran anggaran berimplikasi pada aparat pelaksana untuk menyusun anggaran sesuai dengan sasaran yang ingin dicapai instansi pemerintah. Abdullah (2004) menyatakan bahwa arah dan kebijakan umum anggaran daerah pada dasarnya memuat informasi mengenai tujuan dan sasaran yang akan dicapai oleh daerah yang bersangkutan dalam tahun anggaran tertentu.

\section{Pelaporan}

Mardiasmo (2002:160) menyatakan bahwa pemerintah daerah sebagai organisasi memiliki kewajiban untuk menyajikan laporan keuangan eksternal yang meliputi laporan keuangan formal, seperti laporan surplus/defisit, laporan realisasi anggaran, laporan laba rugi, laporan arus kas, serta laporan kinerja yang dinyatakan dalam ukuran financial dan non financial. Pelaporan merupakan gambaran sistem pertanggungjawaban dari bawahan kepada atasan, dimana pelaporan yang baik sangat diperlukan untuk dapat menilai kinerja dalam mengimplementasikan anggaran yang telah ditetapkan sebelumnya. Kusumaningrum (2010) menyatakan bahwa selaku pengelola dana publik, pemerintah daerah harus mampu memberikan informasi yang akurat, relevan, tepat waktu, konsisten dan dapat dipercaya dapat dipertanggungjawabkan atas pelaksanaan kinerja dalam bentuk laporan.

Sistem pelaporan digunakan untuk memantau hasil kerja yang menunjukkan hasil kerja pusat pertanggungjawaban be- serta anggarannya, dimana pelaporan yang baik yakni yang dibuat secara jujur, obyektif, transparan, relevan, tepat waktu dan konsisten memiliki andil besar dalam meningkatkan akuntabilitas kinerja instansi pemerintah daerah serta sebagai bahan pertimbangan dalam rangka pengambilan keputusan (Zakiyudin dan Suyanto, 2015).

\section{Hubungan antar Variabel}

Schiavo-Campo dan Tomasi (1999) dalam Mardiasmo (2009) menyatakan bahwa pada dasarnya, akuntabilitas adalah pemberian informasi dan pengungkapan (disclosure) atas aktivitas dan kinerja finansial kepada pihak-pihak yang berkepentingan. Akuntabilitas kinerja pengelolaan keuangan pemerintah daerah dapat dinilai baik jika dilaksanakan sesuai aturan yang telah ditetapkan secara baik dan benar, dalam hal ini suatu akuntabilitas dapat dicapai dengan optimal melalui implementasi penganggaran berbasis kinerja sesuai prosedur yang baik tentu saja akan memenuhi kaidah akuntabilitas yakni efektif dan efisien, selain itu juga dengan penerapan pengendalian internal yang baik maka sasaran dari penggunaan keuangan daerah dapat dipertanggungjawabkan dan dapat lebih sesuai sasaran dan tujuan. Akuntabilitas kinerja pengelolaan keuangan pemerintah daerah juga dapat ditunjukkan berdasarkan sasaran-sasaran anggaran yang ditetapkan, dimana kejelasan sasaran anggaran yang baik akan mempermudah dalam mempertanggung-jawabkan keberhasilan atau kegagalan pelaksanaan tugas. Selain itu juga, pelaporan yang baik menunjukkan adanya akuntabilitas terhadap pengelolaan keuangan daerah secara transparan, relevan dan konsisten.

\section{Pengembangan Hipotesis}

Hubungan Penganggaran Berbasis Kinerja terhadap Akuntabilitas Kinerja Pengelolaan Keuangan Pemerintah Daerah

Salah satu upaya pihak agent dalam memberikan pelayanan publik yang optimal, akuntabel dan transparan kepada pihak 
principals adalah menerapkan penganggaran berbasis kinerja. Penganggaran yang terukur dan sesuai dengan prinsip-prinsip akuntabilitas dalam pengelolaan keuangan daerah harus dapat dipertanggungjawabkan, dengan demikian implementasi penganggaran berbasis kinerja yang efektif dan efisien dapat meningkatkan akuntabilitas pemerintah yang transparan kepada masyarakat. Menurut Wibisono (2016) penganggaran yang efektif berarti setiap pengeluaran yang dilakukan pemerintah mengarah pada pencapaian sasaran dan tujuan strategis, sedangkan penganggaran yang efisien mengandung arti bahwa pencapaian sasaran dan tujuan strategis tersebut menggunakan sumberdaya yang paling minimal dengan tetap mempertahankan tingkat kualitas yang direncanakan. Pengalokasian pengeluaran yang efektif, ekonomis dan efisien tersebut dapat diwujudkan dengan implementasi penganggaran berbasis kinerja penganggaran pemerintah daerah.

Penelitian terdahulu oleh Mediawati dan Kurniawan (2012) dan Yani (2014) menyimpulkan bahwa implementasi penganggaran berbasis kinerja berhubungan dengan akuntabilitas kinerja pemerintah daerah. Kuraesin (2014) dan Suriani (2015) mengungkapkan bahwa semakin efektif penganggaran berbasis kinerja diterapkan maka semakin baik kinerja manajerial dan pertanggungjawabannya. Pertanggungjawaban kinerja pada organisasi selaku agen adalah hal yang penting dalam memberikan gambaran mengenai tingkat pencapaian kinerja berupa keberhasilan atau kegagalan kinerja yang telah dicapai kepada prinsipal.

Berdasarkan uraian di atas maka dapat dinyatakan bahwa implementasi penganggaran berbasis kinerja memengaruhi akuntabilitas kinerja pengelolaan keuangan pemerintah daerah yang dirumuskan dalam hipotesis sebagai berikut:

$\mathrm{H}_{1}$ : Implementasi penganggaran berbasis kinerja berpengaruh positif terhadap akuntabilitas kinerja pengelolaan keuangan pemerintah daerah.
Hubungan Pengendalian Internal terhadap Akuntabilitas Kinerja Pengelolaan Keuangan Pemerintah Daerah

Afrina (2015) mengungkapkan bahwa pengendalian internal mempengaruhi akuntabilitas kinerja pengelolaan keuangan pemerintah karena pada dasarnya pengendalian internal berfungsi dalam penyusunan anggaran di dalam menekan terjadinya kesalahan dan penyelewengan dalam menjalankan aktivitas organisasi. Pengendalian internal di pemerintahan daerah dapat menciptakan keseluruhan proses kegiatan yang baik, dengan demikian memberikan keyakinan yang memadai dengan cara meminimalisasi penyimpangan serta memaksimalkan efisiensi dan efektifitas kinerja instansi pemerintah dan tentu saja memberikan dampak positif bagi akuntabilitas kinerja instansi pemerintah. Terciptanya akuntabilitas pemerintah daerah yang baik melalui implementasi pengendalian internal merupakan bentuk tanggungjawab pemerintah sebagai agen dalam pengelolaan dan penyelenggaraan pemerintahan secara transparan, tepat dan jelas kepada prinsipal, selain itu sebagai suatu upaya dalam mewujudkan aspirasi masyarakat dalam rangka mencapai tujuan bersama yakni penyelenggaraan pemerintahan dan pembangunan yang berdaya guna, berhasil guna dan bertanggungjawab.

Penelitian oleh Rahmat (2014) menyatakan bahwa implementasi pengendalian internal berpengaruh dalam meningkatkan atau menurunkan akuntabilitas publik, kesimpulan tersebut didukung dengan hasil penelitian Babatunde (2013) dan Afrida (2013) yang menjelaskan bahwa implementasi pengendalian internal yang baik mengarah kepada kinerja yang lebih baik. Penelitian oleh Primayani et al., (2014) dan Aramide dan Bashir, (2015) juga menyebutkan bahwa dengan adanya pengendalian internal yang optimal dapat menjamin pengelolaan keuangan daerah dilakukan secara konsisten sesuai peraturan perundang-undangan yang berlaku. Berdasarkan kajian teoritis dan penelitian terdahulu 
dapat disimpulkan bahwa implementasi pengendalian internal pada pengelolaan keuangan daerah maka semakin baik pula akuntabilitas kinerja pengelolaan keuangan pemerintah daerah, dengan demikian hipotesis penelitian yang dirumuskan sebagai berikut:

$\mathrm{H}_{2}$ : Implementasi pengendalian internal berpengaruh positif terhadap akuntabilitas kinerja pengelolaan keuangan pemerintah daerah

\section{Hubungan Kejelasan Sasaran Anggaran terhadap Akuntabilitas Kinerja Pengelola- an Keuangan Pemerintah Daerah}

Anggaran merupakan komponen penting dan berkesesuaian pada penyelenggaraan pemerintahan di daerah, hal ini dikarenakan anggaran berdampak pada kinerja dalam pengelolaan keuangan yang dikaitkan dengan fungsi pemerintah dalam memberikan pelayanan kepada masyarakat. Kenis (1979) menyatakan bahwa salah satu karakteristik anggaran adalah kejelasan sasaran anggaran. Pada organisasi sektor publik yakni pemerintah daerah, kejelasan sasaran anggaran tercakup dalam Rencana Pembangunan Jangka Menengah Daerah (RPJMD) dan Rencana Kerja Pemerintah Daerah (RKPD).

Anjarwati (2012) menjelaskan bahwa kejelasan sasaran anggaran berpengaruh baik terhadap akuntabilitas kinerja instansi pemerintah. Pendapat yang sama dikemukakan oleh Setiawan (2013) dan Primayoni et al. (2014) yang menyatakan bahwa kejelasan sasaran anggaran berperan besar dalam meningkatkan akuntabilitas kinerja pemerintah daerah, demikian halnya Kewo (2014) dan Yee et al. (2016) yang mengungkapkan bahwa sasaran anggaran yang jelas dapat memberikan kemudahan penyusunan anggaran dalam rangka mencapai tujuan yang didukung adanya partisipasi penganggaran dan kepahaman yang baik dengan demikian berpengaruh pada kinerja karyawan dan organisasi.

Berdasarkan uraian di atas maka dapat dinyatakan bahwa kejelasan sasaran ang- garan memengaruhi akuntabilitas kinerja pengelolaan keuangan pemerintah daerah yang dirumuskan dalam hipotesis sebagai berikut:

$\mathrm{H}_{3}$ : Kejelasan sasaran anggaran berpengaruh positif terhadap akuntabilitas kinerja pengelolaan keuangan pemerintah daerah.

Hubungan Pelaporan terhadap Akuntabilitas Kinerja Pengelolaan Keuangan Pemerintah Daerah

Pelaporan merupakan bentuk pertanggungjawaban bawahan kepada atasan yang harus objektif dan transparan yang bertujuan memberikan gambaran kinerja dan tindakan seseorang atau organisasi kepada pihakpihak yang memiliki hak atau kewenangan untuk meminta keterangan atau pertanggungjawaban. Nuraini dan Indudewi (2012) mengungkapkan bahwa sistem akuntansi yang mencakup pelaporan yang baik, menciptakan pengelolaan keuangan yang transparan dan akuntabel. Menurut Mardiasmo (2006), laporan yang dihasilkan organisasi publik, sebagai bentuk akuntabilitas publik, seharusnya mengambarkan kondisi yang komprehensif tentang kegiatan operasional, posisi keuangan, arus kas, dan penjelasan (disclosure) atas pos-pos yang ada di dalam laporan keuangan tersebut. Laporan yang disusun adalah dalam rangka memberikan suatu feedback atau umpan balik terhadap suatu kegiatan untuk mengukur capaian kinerja serta meningkatkan akuntabilitas pelaksanaan rencana serta pencapaian tujuan dan sasaran yang ditetapkan.

Herawaty (2011) dan Yulianti et al. (2014) mengungkapkan bahwa pelaporan berpengaruh positif terhadap peningkatan akuntabilitas kinerja instansi pemerintah daerah sehingga menciptakan pengelolaan keuangan yang transparan dan akuntabel. Kloot, (2009) dan Grossi et al., (2016) juga menjelaskan bahwa pelaporan merupakan bagian penting yang berperan dalam meningkatkan akuntabilitas dan sebagai bahan evaluasi kinerja pihak-pihak tertentu dalam membuat keputusan, sehingga pelaporan yang dilakukan 
dengan tidak baik dan lengkap dapat berdampak pada akuntabilitas pada pelayanan publik. Namun demikian Setiawan (2013) menjelaskan bahwa sistem pelaporan tidak berpengaruh terhadap peningkatan akuntabilitas kinerja pemerintah daerah yang disebabkan belum maksimal penerapannya walaupun terdapat sistem akuntansi yang mencakup sistem pelaporan telah cukup memadai. Berdasarkan uraian di atas maka dapat dinyatakan bahwa pelaporan memengaruhi akuntabilitas kinerja pengelolaan keuangan pemerintah daerah yang dirumuskan dalam hipotesis sebagai berikut:

$\mathrm{H}_{4}$ : Pelaporan berpengaruh positif terhadap akuntabilitas kinerja pengelolaan keuangan pemerintah daerah.

\section{METODE PENELITIAN}

Penelitian ini bertujuan untuk menjelaskan pengaruh satu variabel dengan variabel yang lain yang didukung oleh teori dan dalam mengumpulkan data melalui kuesioner, dengan demikian tipe penelitian ini termasuk penelitian eksplanatori (eksplanatory research). Tipe penelitian eksplanatori menurut Sugiyono (2013:6) yaitu penelitian yang digunakan untuk mendapatkan data dari tempat tertentu, tetapi peneliti melakukan perlakuan dalam pengumpulan data, misalnya mengedarkan kuesioner, test, wawancara dan sebagainya.

Populasi pada penelitian ini adalah pegawai negeri sipil (PNS) pengelola keuangan daerah di pemerintah Kabupaten Lombok Barat sesuai strata yakni Kuasa Pengguna Anggaran (KPA), Pejabat Pelaksana Tekhnis Kegiatan (PPTK) dan Pejabat Penatausahaan Keuangan (PPK) yang berjumlah 687 orang yang tersebar di 42 SKPD. Ukuran sampel ditentukan dengan menggunakan rumus Slovin dengan teknik pengambilan sampel menggunakan metode disproportionate stratified random sampling, yakni pengambilan sampel secara acak dengan memperhatikan strata atau tingkatan didalamnya. Hal ini dilakukan mengingat sampel merupakan pengelola keuangan dengan strata jabatan tertentu, dengan demikian jumlah sampel sebesar 87 orang dengan jumlah pada masing-masing tingkatan (strata) adalah 29 orang.

Pengukuran variabel adalah menggunakan skala Likert dengan skor skala 5 poin, sementara itu klasifikasi dan definisi operasional variabel adalah sebagai berikut:

Tabel 1

Klasifikasi dan Definisi Operasional Variabel

\begin{tabular}{|c|c|c|}
\hline Variabel & Definisi & Sumber \\
\hline Akuntabilitas & Kewajiban pihak pemegang amanah untuk & Haspiarti \\
\hline Kinerja & memberikan pertanggungjawaban, menyaji- & $(2012)$ \\
\hline Pemerintah & kan, melaporkan dan mengungkapkan segala & \\
\hline Daerah (AKP) & aktivitas dan kegiatan yang menjadi tang- & \\
\hline & gungjawabnya kepada pihak pemberi amanah & \\
\hline & yang memiliki hak dan kewenangan untuk & \\
\hline & meminta pertanggungjawaban tersebut & \\
\hline Penganggaran & Sistem penganggaran yang berorientasi pada & Haspiarti \\
\hline $\begin{array}{l}\text { Berbasis Kinerja } \\
\text { (PBK) }\end{array}$ & $\begin{array}{l}\text { "output" organisasi dan berkaitan erat dengan } \\
\text { visi, misi, dan rencana strategis organisasi }\end{array}$ & $(2012)$ \\
\hline Pengendalian & Proses yang integral pada tindakan dan & Peraturan \\
\hline \multirow[t]{4}{*}{ Internal (PI) } & kegiatan yang dilakukan secara terus menerus & Pemerintah \\
\hline & oleh pimpinan dan seluruh pegawai untuk & Nomor 60 \\
\hline & memberikan keyakinan memadai atas ter- & Tahun 2008 \\
\hline & $\begin{array}{l}\text { capainya tujuan organisasi melalui kegiatan } \\
\text { yang efektif dan efisien, keandalan pelaporan }\end{array}$ & \\
\hline
\end{tabular}




\begin{tabular}{|c|c|c|}
\hline Variabel & Definisi & Sumber \\
\hline \multirow{5}{*}{$\begin{array}{l}\text { Kejelasan } \\
\text { Sasaran } \\
\text { Anggaran } \\
\text { (KSA) }\end{array}$} & $\begin{array}{l}\text { keuangan, pengamanan aset negara, dan } \\
\text { ketaatan terhadap peraturan perundang- } \\
\text { undangan }\end{array}$ & \\
\hline & Sejauh mana tujuan anggaran ditetapkan & \multirow[t]{4}{*}{ Putra (2013) } \\
\hline & secara jelas dan spesifik dengan tujuan agar & \\
\hline & anggaran tersebut dapat dimengerti oleh & \\
\hline & $\begin{array}{l}\text { orang yang bertanggung-jawab atas pen- } \\
\text { capaian sasaran anggaran tersebut }\end{array}$ & \\
\hline \multirow[t]{6}{*}{ Pelaporan (PEL) } & Sistem yang menggambarkan pertanggung- & \multirow{6}{*}{$\begin{array}{l}\text { Herawaty } \\
(2011)\end{array}$} \\
\hline & jawaban dari bawahan kepada atasan yang & \\
\hline & digunakan untuk memantau dan me- & \\
\hline & ngendalikan kinerja manajerial dalam meng- & \\
\hline & implementasikan anggaran yang telah di- & \\
\hline & tetapkan & \\
\hline
\end{tabular}

Metode analisis data pada penelitian ini dilakukan menggunakan analisis regresi linier berganda, sebelum pengujian hipotesis, terlebih dahulu dilakukan pengujian instrumen penelitian dengan uji reliabilitas dan validitas serta pengujian kualitas data melalui uji asumsi klasik. Persamaan regresi linier berganda untuk hipotesis penelitian adalah sebagai berikut:

$\mathrm{AKP}=a+\mathrm{b}_{1} \mathrm{PBK}+\mathrm{b}_{2} \mathrm{PI}+\mathrm{b}_{3} \mathrm{KSA}+\mathrm{b}_{4} \mathrm{PEL}+e$

Keterangan:

\begin{tabular}{|c|c|}
\hline AKP & $\begin{aligned}= & \text { Akuntabilitas Kinerja Peme- } \\
& \text { rintah Daerah }\end{aligned}$ \\
\hline$a$ & $=$ Konstanta \\
\hline$b_{1} b_{2} b_{3} b_{4}$ & $\begin{aligned} &= \text { Koefisien regresi untuk ma- } \\
& \text { sing-masing variabel inde- } \\
& \text { penden }\end{aligned}$ \\
\hline PBK & $\begin{aligned}= & \text { Implementasi Penganggar- } \\
& \text { an Berbasis Kinerja }\end{aligned}$ \\
\hline PI & $\begin{aligned}= & \text { Implementasi Pengendalian } \\
& \text { Internal }\end{aligned}$ \\
\hline KSA & $=$ Kejelasan Sasaran Anggaran \\
\hline${ }^{\circ} \mathrm{E}$ & $=$ Pelaporan \\
\hline & $=$ Residual \\
\hline
\end{tabular}

Pengujian hipotesis pada analisis data dilakukan untuk mengetahui ada tidaknya pengaruh variabel independen terhadap variabel dependen baik secara simultan maupun parsial. Tingkat kesalahan (a) yang digunakan dalam melakukan pengujian hipotesis adalah sebesar 5\%, sementara itu uji hipotesis yang dilakukan adalah sebagai berikut:

\section{Uji Signifikan Parameter Individual (Uji Statistik $\mathbf{t}$ )}

Uji statistik $t$ pada dasarnya menunjukkan seberapa jauh pengaruh satu variabel penjelas/independen secara individual menerangkan variasi variabel dependen. Dengan asumsi variabel lain tetap. Uji $t$ dapat dilakukan dengan melihat nilai probabilitas signifikansi $t$ masing-masing variabel yang terdapat pada output hasil regresi. Jika nilai probabilits signifikansi t lebih kecil dari 0,05 maka dapat dikatakan bahwa ada pengaruh yang kuat antara variabel independen dengan variabel dependen (Ghozali, 2013:97).

\section{ANALISIS DAN PEMBAHASAN \\ Analisis Data \\ Pengujian Validitas dan Reliabilitas}

Suatu penelitian yang memadai apabila suatu data penelitian valid, reliabel dan obyektif, sehingga suatu data penelitian dianggap akurat maka dari itu perlu dilakukan pengujian validitas dan realibilitas. Uji validitas pada instrumen penelitian ini dilakukan dengan menguji instrumen per variabel. Validitas diukur dengan menggunakan korelasi bivariate pearson (Product Moment Pearson), dengan kriteria $r$ hitung $\geq \mathrm{r}$ tabel pada tingkat signifikan 0,05 (5\%). 
Sedangkan Uji reliabilitas pada penelitian ini menggunakan uji statistik Cronbach Alpha, suatu konstruk atau variabel dikatakan reliabel jika memberikan nilai Cronbach Alpha $>0,70$ (Ghozali, 2013).

Tabel 2

Pengujian Validitas dan Reliabilitas

\begin{tabular}{|c|c|c|c|}
\hline \multirow[b]{2}{*}{ No } & \multirow[b]{2}{*}{ Variabel } & \multicolumn{2}{|c|}{ Validitas dan Reliabilitas } \\
\hline & & Koefisien/r $\mathbf{r}_{\text {hitung }}$ & $\begin{array}{l}\text { Cronbach's } \\
\text { Alpha }\end{array}$ \\
\hline 1 & $\begin{array}{l}\text { Akuntabilitas Kinerja Pemerintah } \\
\text { Daerah }\end{array}$ & $0,646-0,846$ & 0.895 \\
\hline 2 & Penganggaran Berbasis Kinerja & $0,452-0,757$ & 0.852 \\
\hline 3 & Pengendalian Internal & $0,569-0,767$ & 0.692 \\
\hline 4 & Kejelasan Sasaran Anggaran & $0,662-0,833$ & 0.853 \\
\hline 5 & Pelaporan & $0,856-0,886$ & 0.844 \\
\hline
\end{tabular}

Hasil uji validitas untuk semua variabel menunjukkan bahwa semua variabel memiliki kisaran koefisien atau $r_{\text {hitung }}$ yang diatas nilai $r$ tabel dimana nilai $r$ tabel yang diperoleh adalah sebesar 0,213 dengan demikian berdasarkan kriteria yang ditentukan dapat disimpulkan bahwa seluruh item pernyataan adalah dinyatakan valid. Sementara untuk uji validitas, berdasarkan tabel 2 dapat disimpulkan bahwa kelima variabel memiliki nilai cronbach alpha $>0,70$ sehingga dapat disimpulkan bahwa pengukuran instrumen keseluruhan variabel dinyatakan reliabel (andal).

\section{Pengujian Asumsi Klasik Uji Multikolinearitas}

Uji multikolinearitas dapat dilihat dari besarnya nilai tolerance dan Variance Inflation Factor (VIF), apabila nilai tolerance $<0,10$ atau VIF > 10, maka dapat disimpulkan bahwa terdapat gejala multikolinearitas (Ghozali, 2013:106).

Tabel 3

Hasil Uji Multikolinieritas

\begin{tabular}{lccc}
\hline \multicolumn{1}{c}{ Variabel } & Tolerance & VIF & Keterangan \\
\hline Penganggaran Berbasis Kinerja & 0.468 & 2.135 & Bebas Multikolinearitas \\
Pengendalian Internal & 0.281 & 3.557 & Bebas Multikolinearitas \\
Kejelasan Sasaran Anggaran & 0.431 & 2.318 & Bebas Multikolinearitas \\
Pelaporan & 0.511 & 1.958 & Bebas Multikolinearitas \\
\hline
\end{tabular}

Sumber: output SPSS 16, 2017 diolah

Berdasarkan hasil output seperti yang tertera pada tabel 3, nilai tolerance untuk semua variabel independen adalah $>0,10$ yang berarti tidak terdapat korelasi antar variabel independen Demikian halnya dengan melihat nilai VIF, keempat variabel independen adalah lebih kecil dari $10(<10)$ sehingga dapat disimpulkan bahwa tidak terjadi gejala mulitikolinieritas.

\section{Uji Heteroskedastisitas}

Model regresi yang memenuhi persyaratan adalah di mana terdapat kesamaan varians dari residual satu pengamatan ke 
pengamatan yang lain tetap atau disebut homoskedastisitas, seperti yang diungkapkan oleh Ghozali, (2013:139) bahwa model regresi yang baik adalah yang homos- kedastisitas atau tidak terjadi heteroskedastisitas. Uji yang dilakukan pada uji heteroskedastisitas adalah uji glejser dengan kriteria uji adalah nilai signifikansi $>5 \%$.

Tabel 4

Uji Glejser

\begin{tabular}{lcccc}
\hline \multirow{2}{*}{ Variabel } & \multirow{2}{*}{ Tolerance } & \multicolumn{2}{c}{ Alpha } & \multirow{2}{*}{ Keterangan } \\
\cline { 3 - 4 } & & $\mathbf{1 \%}$ & $\mathbf{5 \%}$ & \\
\hline Penganggaran Berbasis Kinerja & 0.122 & 0.01 & 0.05 & Bebas Heteroskedastisitas \\
Pengendalian Internal & 0.993 & 0.01 & 0.05 & Bebas Heteroskedastisitas \\
Kejelasan Sasaran Anggaran & 0.011 & 0.01 & 0.05 & Bebas Heteroskedastisitas \\
Pelaporan & 0.776 & 0.01 & 0.05 & Bebas Heteroskedastisitas \\
\hline
\end{tabular}

Sumber: output SPSS 16, 2017 diolah

Hasil uji glejser yang dilakukan hasil adalah seperti yang terlihat pada tabel 4, dimana berdasarkan kriteria uji yang ditentukan maka dapat disimpulkan bahwa tidak terjadi gejala heteroskedastisitas pada model regresi.

\section{Uji Normalitas}

Uji normalitas dilakukan dengan menggunakan uji Kolmogorov-Smirnov (K-S), dengan kriteria pengujian adalah jika nilai signifikansi (asymp.) lebih dari 5\% maka dapat dikatakan bahwa residual data dari model regresi adalah terdistribusi secara normal (Ghozali, 2013:165). Hasil uji kolmogorov smirnov seperti yang terlihat pada tabel 5 sebagai berikut.

\section{Koefisien Determinasi $\left(\mathbf{R}^{2}\right)$}

Koefisien determinasi $\left(\mathrm{R}^{2}\right)$ digunakan untuk melihat kemampuan model dalam menjelaskan variabel independen terhadap variabel dependen dari model yang dibangun.

Tabel 5

Uji Kolmogorov Smirnov

\begin{tabular}{|c|c|c|c|c|}
\hline \multicolumn{3}{|c|}{ Keterangan } & \multicolumn{2}{|c|}{ Unstandardized Residual } \\
\hline \multicolumn{3}{|c|}{$\mathrm{N}$} & \multicolumn{2}{|r|}{87} \\
\hline \multicolumn{3}{|c|}{ Kolmogorov-Smirnov Z } & \multicolumn{2}{|r|}{1.072} \\
\hline \multicolumn{3}{|c|}{ Asymp. Sig. (2-tailed) } & \multicolumn{2}{|r|}{.201} \\
\hline \multicolumn{5}{|c|}{ Sumber: output SPSS 16, 2017 diolah } \\
\hline \multicolumn{5}{|c|}{$\begin{array}{c}\text { Tabel } 6 \\
\text { Koefisien Determinasi }\left(R^{2}\right)\end{array}$} \\
\hline \multicolumn{5}{|c|}{ Model Summary } \\
\hline Model & $\mathbf{R}$ & R Square & $\begin{array}{c}\text { Adjusted R } \\
\text { Square }\end{array}$ & $\begin{array}{c}\text { Std. Error of the } \\
\text { Estimate }\end{array}$ \\
\hline 1 & $.758^{\mathrm{a}}$ & .575 & .554 & .13210 \\
\hline
\end{tabular}

a. Predictors: (Constant), PEL, PBK, KSA, PI

Sumber: output SPSS 16, 2017 diolah 
Berdasarkan tabel 6 diperoleh nilai $\mathrm{R}$ adalah sebesar 0,758 dan nilai adjusted $\mathrm{R}$ Square adalah sebesar 0,554. Hal ini menunjukkan bahwa kekuatan hubungan variabel penganggaran berbasis kinerja, pengendalian internal, kejelasan sasaran anggaran dan pelaporan adalah sebesar $75,8 \%$, sedangkan kemampuan variabel independen menjelaskan variasi pada variabel dependen mencapai 55,4\% atau dapat dikatakan bahwa kemampuan variabel independen dalam menjelaskan variasi variabel dependen adalah sebesar 55,4\%, sedangkan sisanya sebesar $44,6 \%$ dijelaskan oleh variabel lain di luar model yang dibangun pada penelitian ini.

\section{Pengujian Hipotesis}

\section{Uji Signifikansi Parameter Individual (Uji Statistik $\mathbf{t}$ )}

Uji statistik $\mathrm{t}$ adalah digunakan untuk menguji hipotesis secara individu, berdasarkan tabel 7 dapat dijelaskan pengaruh masing-masing variabel independen terhadap variabel dependen sebagai berikut:

1. Variabel penganggaran berbasis kinerja (PBK) memiliki nilai signifikansi sebesar 0,008 dengan demikian berdasarkan kriteria pengujian yakni $0,008<0,05$ hal ini menunjukkan $\mathrm{H}_{0}$ ditolak atau dapat dikatakan bahwa penganggaran berbasis kinerja berpengaruh positif terhadap akuntabilitas kinerja pengelolaan keuangan pemerintah daerah.

2. Variabel pengendalian internal (PI) memiliki nilai signifikansi sebesar 0,001 dimana berdasarkan kriteria pengambilan keputusan yakni 0,001 <0,005 atau $\mathrm{H}_{0}$ ditolak. Hal ini menunjukkan bahwa pengendalian internal berpengaruh positif terhadap akuntabilitas kinerja pengelolaan keuangan pemerintah daerah.

3. Variabel kejelasan sasaran anggaran (KSA) berdasarkan memiliki nilai signifikansi sebesar 0,001, berdasarkan kriteria pengambilan keputusan maka $\mathrm{H}_{0}$ ditolak karena 0,001<0,05. Hal ini menunjukkan bahwa kejelasan sasaran anggaran berpengaruh positif terhadap akuntabilitas kinerja pengelolaan keuangan pemerintah daerah.

4. Variabel pelaporan (PEL) berdasarkan output SPSS pada tabel 7 memiliki nilai signifikansi sebesar 0,002 sehingga berdasarkan kriteria pengambilan keputusan maka $\mathrm{H}_{0}$ ditolak dimana $0,002<0,05$. Hal ini menunjukkan bahwa pelaporan berpengaruh positif terhadap akuntabilitas kinerja pengelolaan keuangan pemerintah daerah.

Berdasarkan hasil pengujian pada tabel 7 diperoleh persamaan model regresi berganda sebagai berikut: $A K P=-0,626+$ $0,287 P B K+0,556 P I+0,340 K S A+0,198 P E L$

Tabel 7

Uji Signifikan Parameter Individual (Uji Statistik $t$ )

Coefficients $^{\mathrm{a}}$

\begin{tabular}{|c|c|c|c|c|c|c|}
\hline & \multirow{2}{*}{ Model } & \multicolumn{2}{|c|}{ Unstandardized Coefficients } & \multirow{2}{*}{$\begin{array}{c}\text { Standardized } \\
\text { Coefficients } \\
\text { Beta } \\
\end{array}$} & \multirow[t]{2}{*}{$\mathbf{t}$} & \multirow{2}{*}{ Sig. } \\
\hline & & $\mathbf{B}$ & Std. Error & & & \\
\hline \multirow[t]{5}{*}{1} & (Constant) & -.626 & .474 & & -1.320 & .191 \\
\hline & PBK & .287 & .106 & .275 & 2.708 & .008 \\
\hline & PI & .556 & .156 & .447 & 3.565 & .001 \\
\hline & KSA & .340 & .096 & .363 & 3.537 & .001 \\
\hline & PEL & .198 & .061 & .344 & 3.263 & .002 \\
\hline
\end{tabular}

a. Dependent Variable: AKP

Sumber : Output SPSS 16, 2017 diolah 


\section{Pembahasan}

Akuntabilitas mempunyai arti pertanggungjawaban yang menjadi salah satu ciri dari penerapan good governance (tata kelola yang baik) yang bersumber pada pengelolaan administrasi publik dan merupakan isu utama dalam pencapaian menuju clean government (pemerintahan yang bersih). Tata kelola pemerintahan yang akuntabel akan mendapat dukungan dan kepercayaan dari publik atas pelaksanaan program berorientasi kepada publik, serta diyakini mampu mengubah kondisi pemerintahan yang tidak dapat memberikan pelayanan publik secara baik dan korup menuju suatu tatanan pemerintahan yang demokratis.

Berdasarkan peraturan perundangundangan yang berlaku, pemerintah daerah diharuskan membuat pertanggungjawaban pengelolaan keuangan selaku agent kepada principal yang diwujudkan dalam bentuk laporan akuntabilitas kinerja pemerintah atau LAKIP. Akuntabilitas kinerja pengelolaan keuangan pemerintah daerah khususnya di Kabupaten Lombok Barat harus terus ditingkatkan sebagai jaminan dan sasaran strategis untuk peningkatan kinerja dalam mewujudkan tata kelola pemerintahan yang baik dan meningkatkan kualitas pelayanan publik.

\section{Pengaruh Penganggaran Berbasis Kinerja terhadap Akuntabilitas Kinerja Pengelola- an Keuangan Pemerintah Daerah}

Akuntabilitas publik adalah kewajiban pihak pemegang amanah (agen) untuk memberikan pertanggungjawaban kepada pihak pemberi amanah (prinsipal). Dalam rangka meningkatkan akuntabilitas publik tersebut maka salah satunya adalah menerapkan penganggaran berbasis kinerja, dimana penganggaran berbasis kinerja dianggap sebagai salah satu solusi dalam mengatasi kelemahan ketiadaan tolok ukur kinerja dalam pencapaian tujuan dan sasaran pelayanan publik. Penganggaran yang terukur dan sesuai dengan prinsip-prinsip akuntabilitas dalam pengelolaan keuangan daerah harus dapat dipertanggungjawabkan, dengan demikian penganggaran yang dilaksanakan secara optimal dapat meningkatkan akuntabilitas secara transparan, efektif dan efisien.

Hasil penelitian ini mengungkapkan bahwa implementasi penganggaran berbasis kinerja di Kabupaten Lombok Barat telah diterapkan dengan baik, dimana pejabat pengelola keuangan telah melaksanakannya melalui perencanaan, implementasi anggaran, pelaporan anggaran dan evaluasi kinerja program serta kegiatan berdasarkan peraturan-peraturan yang berlaku. Berdasarkan pengujian hipotesis yang dilakukan, secara statistik ditunjukkan bahwa penganggaran berbasis kinerja berpengaruh positif terhadap akuntabilitas kinerja pengelolaan keuangan pemerintah daerah di Kabupaten Lombok Barat.

Berpengaruh positif mengandung arti bahwa implementasi penganggaran berbasis kinerja berkorelasi secara positif terhadap akuntabilitas kinerja pemerintah daerah dalam pengelolaan keuangan, hal ini mengindikasikan bahwa penganggaran berbasis kinerja yang diterapkan berorientasi pada hasil, berkaitan dengan visi dan misi serta rencana organisasi dapat berdampak positif pada pertanggungjawaban. Berdasarkan hasil penelitian, SKPD pada lingkup pemerintah Kabupaten Lombok Barat telah melaksanakan penganggaran berbasis kinerja sesuai unsur-unsur yang mendasarinya serta fokus terhadap efisiensi pelaksanaan kegiatan.

Hasil penelitian ini sejalan dengan penelitian oleh Mediawati dan Kurniawan (2012), Yani (2014) dan Kuraesin (2014) yakni adanya hubungan antara implementasi penganggaran berbasis kinerja dengan akuntabilitas kinerja pemerintah daerah. Penelitian ini menunjukkan bahwa semakin efektif penganggaran berbasis kinerja maka akan mempengaruhi kinerja manajerial. Hasil pengujian hipotesis ini juga mendukung daripada penelitian Endrayani et al. (2014) dan Suriani (2015) yang menjelaskan bahwa implementasi penganggaran berbasis 
kinerja yang baik dan efektif memengaruhi akuntabilitas kinerja pemerintah daerah terhadap pengelolaan keuangan daerah.

Hasil penelitian ini mendukung dan memperkuat teori keagenan karena dapat membuktikan bahwa penganggaran berbasis kinerja adalah faktor pendukung dalam peningkatan akuntabilitas kinerja pengelolaan keuangan pemerintah daerah di Kabupaten Lombok Barat. Hasil penelitian ini juga relevan terhadap teori Stewardship, yang menggambarkan hubungan antara stewards yakni pemerintah daerah dan principals atas dasar kepercayaan serta bertindak kolektif sesuai dengan tujuan organisasi.

Pengaruh Pengendalian Internal terhadap Akuntabilitas Kinerja Pengelolaan Keuangan Pemerintah Daerah

Pengawasan sesungguhnya mencakup aspek pengendalian maupun aspek pemeriksaan yang dilakukan atasan terhadap bawahan, dimana pengawasan memiliki fungsi dalam membandingkan antara hasil yang dicapai dengan yang telah direncanakan, oleh karena itu dengan adanya pengawasan melalui sistem pengendalian internal (SPI), diharapkan dapat memberikan keyakinan memadai bagi prinsipal terhadap pencapaian kinerja pengelolaan keuangan oleh agen yang akuntabel, efisien dan efektif.

Hasil pengujian hipotesis pada penelitian ini menunjukkan bahwa pengendalian internal berpengaruh positif terhadap akuntabilitas kinerja pengelolaan pemerintah daerah. Hal ini menunjukkan bahwa penerapan pengendalian internal telah berjalan dengan baik berdasarkan komponenkomponen pengendalian seperti yang dituangkan pada Peraturan Pemerintah Nomor 60 tahun 2008 tentang Sistem Pengendalian Internal Pemerintah (SPIP). Berpengaruh positif mengandung arti bahwa peningkatan akuntabilitas kinerja pemerintah di Kabupaten Lombok Barat adalah ditentukan oleh pelaksanaan pengendalian internal terhadap pengelolaan keuangan daerah oleh masing-masing SKPD, semakin baik diterapkan maka semakin baik pula pertanggungjawaban yang diberikan.

Hasil penelitian ini sejalan dengan beberapa penelitian terdahulu yang menunjukkan bahwa terdapat pengaruh antara faktor pengendalian internal terhadap peningkatan akuntabilitas kinerja pemerintah daerah. Seperti penelitian yang dilakukan Rahmat (2014), Babatunde (2013) dan Afrida (2013) yang menyatakan bahwa implementasi sistem pengendalian internal berdasarkan Peraturan Pemerintah Nomor 60 tahun 2008 berpengaruh dalam meningkatkan akuntabilitas kinerja pemerintah daerah, karena sistem pengendalian internal yang memadai mengarah pada kinerja manajerial yang lebih baik. Demikian halnya penelitian yang dilakukan oleh Primayani et al., (2014) dan Aramide dan Bashir, (2015) yang menyebutkan bahwa dengan pengendalian internal yang optimal dapat menjamin pengelolaan keuangan daerah serta menghindari dampak timbulnya korupsi.

Hasil penelitian ini mendukung sekaligus memperkuat teori keagenan oleh Jensen dan Meckling (1976) karena pengendalian internal pada SKPD merupakan faktor pendukung dalam meningkatkan akuntabilitas kinerja pengelolaan keuangan pemerintah daerah di Kabupaten Lombok Barat.

Pengaruh Kejelasan Sasaran Anggaran terhadap Akuntabilitas Kinerja Pengelolaan Keuangan Pemerintah Daerah

Pengelolaan keuangan pada pemerintah daerah yang berakuntabilitas tidak lepas dari anggaran pemerintah daerah. Anggaran diperlukan dalam pengelolaan sumber daya tersebut dengan baik untuk mencapai kinerja yang diharapkan dan menciptakan akuntabilitas terhadap masyarakat selaku pemberi amanah, oleh karena itu kejelasan sasaran anggaran diperlukan agar diketahui sejauh mana tujuan anggaran ditetapkan dan dimengerti agar dalam penyusunan anggaran yang dilakukan dapat sesuai dengan tujuan instansi pemerintah. 
Hasil penelitian ini menunjukkan bahwa penganggaran yang dilaksanakan di pemerintah Kabupaten Lombok Barat oleh SKPD adalah berdasarkan sasaran-sasaran yang ditetapkan serta tujuan yang ingin dicapai. Hasil pengujian hipotesis mengungkapkan bahwa kejelasan sasaran anggaran oleh SKPD di Kabupaten Lombok Barat pada pengelolaan keuangan daerah berpengaruh positif terhadap akuntabilitas kinerja pemerintah daerah. Hasil penelitian juga menunjukkan bahwa SKPD pada lingkup pemerintah Kabupaten Lombok Barat memiliki pemahaman yang baik dalam menetapkan sasaran anggaran sehingga tidak menimbulkan kebingungan dalam menyelesaikan pekerjaan dan selalu bekerja sama dalam mencapai tujuan yang berarti juga adanya peningkatan kinerja penyusun anggaran sekaligus peningkatan akuntabilitas terhadap kinerja.

Hasil penelitian ini sesuai dengan beberapa penelitian terdahulu seperti penelitian oleh Anjarwati (2012) dan Setiawan (2013) yang menemukan bahwa kejelasan sasaran anggaran berpengaruh positif terhadap akuntabilitas kinerja pemerintah daerah. Penelitian ini juga sejalan dengan penelitian Primayoni et al. (2014) dan Yee et al. (2016) yang menjelaskan bahwa sasaran anggaran yang jelas dapat meningkatkan akuntabilitas kinerja pemerintah daerah dengan didukung oleh adanya partisipasi dalam penganggaran sehingga dapat mencapai tujuan yang sulit sekalipun. Demikian halnya Kewo (2014) yang membuktikan bahwa kejelasan sasaran anggaran berperan dalam meningkatkan akuntabilitas kinerja melalui kesepahaman yang baik dalam menetapkan sasaran anggaran dimana kemudahan penyusunan anggaran berdampak pada kemudahan pertanggungjawaban kinerja.

Hasil penelitian ini memperkuat dan mendukung agency theory terkait adanya hubungan kontraktual antara principal dengan agent, dimana agen diberikan wewenang untuk mengelola anggaran dan mempertanggungjawabkan pengelolaannya kepada prinsipal. Pengelolaan anggaran oleh agen dengan menetapkan sasaran anggaran yang jelas dapat mempermudah penyusunan anggaran sesuai tujuan yang ingin dicapai bersama dan disaat yang bersamaan meningkatkan kinerja para penyusunnya sekaligus mempermudah pertanggungjawaban pengelolaannya.

\section{Pengaruh Pelaporan terhadap Akunta- bilitas Kinerja Pengelolaan Keuangan Pemerintah Daerah}

Berdasarkan peraturan perundangundangan yang berlaku, pemerintah daerah memiliki kewajiban dalam memberikan laporan yang berisi informasi keuangan dan kinerja yang berguna dalam memberikan umpan balik (feedback) untuk mengukur pelaksanaan kegiatan dalam rangka meningkatkan kinerja dan akuntabilitas. Sebagai bagian dari pertanggungjawaban, laporan harus dijabarkan secara objektif dan transparan untuk mengetahui sejauh mana kinerja sesorang atau organisasi kepada pihak-pihak yang memiliki kewenangan untuk meminta pertanggungjawaban.

Hasil penelitian berdasarkan pengujian hipotesis menunjukkan bahwa pelaporan berpengaruh positif dalam meningkatkan akuntabilitas kinerja pengelolaan keuangan pemerintah daerah. Berpengaruh positif dapat dijelaskan bahwa pelaporan yang baik pada pengelolaan keuangan daerah dapat mempengaruhi peningkatan akuntabilitas pemerintah daerah. Hasil penelitian juga menunjukkan bahwa pelaporan yang dilakukan SKPD telah disusun secara sistematis berdasarkan peraturan dan perundang-undangan yang berlaku sehingga dapat berguna sebagai bahan evaluasi untuk mengukur kegiatan-kegiatan yang dilaksanakan dengan tujuan meningkatkan kinerja dengan demikian dapat diketahui sejauh mana pencapaian dari target-target yang telah ditetapkan.

Hasil penelitian ini sesuai dengan penelitian yang dilakukan oleh Herawaty (2011) dan Yulianti et al. (2014) yang menyimpulkan bahwa sistem pelaporan berpengaruh positif terhadap akuntabilitas 
kinerja instansi pemerintah daerah. Hasil penelitian ini juga sejalan dengan penelitian oleh Kloot, (2009) dan Grossi et al., (2016) yang menyebutkan bahwa sistem pelaporan memiliki dampak terhadap akuntabilitas kinerja dan dapat dipergunakan sebagai bahan evaluasi pihak-pihak tertentu. Hasil penelitian ini tidak sesuai dengan penelitian oleh Setiawan (2013) yang menyatakan bahwa sistem pelaporan tidak berpengaruh dalam meningkatkan akuntabilitas kinerja pemerintah daerah walaupun sistem pelaporan yang dilakukan telah cukup memadai dan tercakup pada sistem akuntansi yang dimiliki.

Hasil penelitian ini mendukung dan memperkuat daripada teori keagenan yang menyatakan adanya hubungan agensi ketika principals mendelegasikan wewenang kepada agent, dimana principals memiliki kewenangan untuk meminta pertanggungjawaban dalam bentuk suatu laporan, karena pelaporan merupakan faktor pendukung dalam meningkatkan akuntabilitas kinerja pemerintah daerah sehingga dapat dipergunakan secara maksimal oleh pihakpihak tertentu. Hasil penelitian ini juga relevan terhadap teori lainnya yakni teori Legitimasi oleh Deegan et al. (2002) yang menjelaskan bahwa pengungkapan tanggung jawab sosial dilakukan untuk mendapatkan legitimasi dari masyarakat. Pemerintah daerah selaku penerima amanah dalam pengelolaan keuangan sepatutnya memberikan pertanggungjawaban yang layak dalam bentuk laporan yang objektif dan transparan kepada pemberi amanah.

\section{SIMPULAN DAN SARAN \\ Simpulan}

Berdasarkan penelitian yang dilakukan, dapat disimpulkan bahwa penganggaran berbasis kinerja berpengaruh positif terhadap akuntabilitas kinerja pengelolaan keuangan pemerintah Kabupaten Lombok Barat. Hal ini berarti bahwa penerapan penganggaran berbasis kinerja telah sangat baik diterapkan karena tolok ukur keberhasilan penganggaran berbasis kinerja adalah adanya keterkaitan antara dana yang tersedia dengan hasil yang diharapkan. Penelitian ini membuktikan bahwa pengendalian internal berpengaruh positif terhadap akuntabilitas kinerja pengelolaan keuangan pemerintah Kabupaten Lombok Barat. Hal ini menunjukkan bahwa penerapan pengendalian internal terhadap pengelolaan keuangan daerah oleh masingmasing SKPD berperan dalam meningkatkan akuntabilitas kinerja pemerintah di Kabupaten Lombok Barat.

Penelitian ini dapat membuktikan bahwa kejelasan sasaran anggaran berpengaruh positif dalam meningkatkan akuntabilitas kinerja pemerintah Kabupaten Lombok Barat dalam mengelolaa keuangan daerah. Hal ini berarti bahwa para pimpinan SKPD pada lingkup pemerintah Kabupaten Lombok Barat dalam melakukan penyusunan anggaran berpedoman pada sasaran-sasaran anggaran yang jelas dan dapat dipahami dalam rangka meningkatkan akuntabilitas kinerja. Penelitian ini membuktikan bahwa sistem pelaporan berpengaruh secara positif terhadap peningkatan akuntabilitas kinerja pemerintah Kabupaten Lombok Barat, hal ini membuktikan penyusunan laporan telah dilakukan dengan baik, sehingga membantu peningkatan akuntabilitas kinerja pemerintah khususnya di Kabupaten Lombok Barat, dimana pelaporan yang baik akan mencantumkan penjelasan mengenai penyebab terjadinya penyimpangan, tindakan yang diambil untuk mengoreksi penyimpangan yang tidak menguntungkan dan waktu yang dibutuhkan agar tindakan koreksi lebih efektif.

\section{Implikasi Penelitian}

Hasil penelitian ini dapat memberikan implikasi bahwa dalam pengelolaan keuangan daerah, SKPD pada lingkup pemerintah Kabupaten Lombok Barat pada khususnya dapat mempertimbangkan aspek penganggaran berbasis kinerja, pengendalian internal, kejelasan sasaran anggaran dan pelaporan dalam meningkatkan akuntabilitas kinerja untuk menciptakan pengelola- 
an keuangan daerah yang profesional, transparan dan akuntabel. Hasil temuan dalam penelitian ini dapat dipergunakan sebagai bahan masukan dan pertimbangan bagi pemerintah daerah dan legislatif yakni dalam menyelenggarakan pembangunan melalui pengelolaan keuangan yang efektif dan efisien adalah memperhatikan dan mempertimbangkan faktor-faktor yang memengaruhi akuntabilitas kinerja pemerintah daerah yakni aspek penganggaran berbasis kinerja, sistem pengendalian internal, kejelasan sasaran anggaran dan sistem pelaporan.

\section{Saran Penelitian}

Beberapa saran yang dapat diberikan dalam penelitian-penelitian mendatang yang berhubungan dengan akuntabilitas kinerja pengelolaan keuangan daerah diantaranya adalah memperluas objek penelitian, misalnya pada tingkat Provinsi NTB atau beberapa Kabupaten/Kota pada 1 (satu) pulau di Provinsi NTB dan bahkan Provinsi lain di luar Provinsi NTB. Penelitian selanjutnya disarankan dapat menambahkan variabel langsung maupun variabel tidak langsung yakni variabel independen lain atau variabel moderasi dan intervening, atau bahkan memberikan tambahan variabel dependen sehingga hasil penelitian dan kesimpulan yang diperoleh lebih spesifik dan komprehensif. Penelitian selanjutnya diharapkan mengembangkan faktor-faktor lain yang mempengaruhi akuntabilitas kinerja pemerintah daerah. Variabel lainnya yang dipertimbangkan untuk digunakan seperti pengendalian akuntansi, motivasi, partisipasi anggaran dan tingkat pelayanan pemerintah daerah. Variabel-variabel tersebut dapat digunakan sebagai variabel dependen, variabel intervening atau bahkan variabel moderasi.

\section{Keterbatasan Penelitian}

Keterbatasan pada penelitian ini memiliki pengaruh pada hasil penelitian, oleh karena itu dapat diperbaiki pada penelitian selanjutnya. Ruang lingkup pada penelitian ini hanya dilakukan pada pemerintah Kabupaten Lombok Barat, sehingga perbedaan hasil penelitian dapat terjadi jika dilakukan pada pemerintah daerah yang berbeda atau di beberapa pemerintah daerah. Penelitian ini menggunakan 4 (empat) variabel independen yang mempengaruhi langsung terhadap akuntabilitas kinerja pemerintah daerah, sehingga kurang mengeksplorasi faktor-faktor lainnya yang tidak langsung seperti variabel moderasi atau variabel intervening yang mungkin menghasilkan kesimpulan yang lebih baik. Penelitian ini kurang mengeksplorasi faktor-faktor lain yang diduga berpengaruh terhadap akuntabilitas kinerja pemerintah daerah, sementara itu masih terdapat faktor-faktor lain yang mempengaruhi akuntabilitas kinerja pemerintah daerah seperti kualitas SDM, optimalisasi teknologi informasi, motivasi anggaran atau kualitas pelayanan pemerintah daerah dan tingkat kepuasan masyarakat.

\section{DAFTAR PUSTAKA}

Abdullah, H. 2004. Pengaruh Kejelasan Sasaran Anggaran, Pengendalian Akuntansi dan Sistem Pelaporan terhadap Akuntabilitas Kinerja Instansi Pemerintah (Studi Empiris pada Kabupaten dan Kota Daerah Istimewa Yogyakarta). Disertasi. Universitas Gajah Mada. Yogyakarta.

Afrida, N. 2013. Pengaruh Desentralisasi dan Sistem Pengendalian Intern Pemerintah terhadap Kinerja Manajerial SKPD (Studi Empiris pada Pemerintah Kota Padang). Skripsi. Program Studi Akuntansi, Fakultas Ekonomi, Universitas Negeri Padang. Padang.

Afrina, D. 2015. Pengaruh Penerapan Sistem Akuntansi Pemerintah Daerah, Pengendalian Intern dan Sistem Pelaporan Terhadap Akuntabilitas Kinerja Instansi Pemerintah (Studi Persepsian pada Satuan Kerja Perangkat Daerah Kota Pekanbaru). JOM FEKON 2(2).

Anjarwati, M. 2012. Pengaruh Kejelasan Sasaran Anggaran, Pengendalian Akun- 
tansi dan Sistem Pelaporan terhadap AKIP. Accounting Analysis Journal 1(2): 17.

Aramide, S. F. dan M. M. Bashir. 2015. The Effectiveness of Internal Control System and Financial Accountability at Local Government Level in Nigeria. International Journal of Research in Bussines Management 3(8): 1-6.

Babatunde, S. A. 2013. Stakeholders Perception on the Effectiveness of Internal Control System on Financial Accountability in the Nigerian Public Sector. International Journal of Bussiness and Management Invention 2(1): 16-33.

Bastian, I. 2006. Akuntansi Sektor Publik: Suatu Pengantar. Penerbit Erlangga. Jakarta.

Damayanti, S. 2017. Pengaruh Pengendalian Internal, Pemanfaatan Teknologi Informasi dan Akuntabilitas Publik Terhadap Kinerja Instansi Pemerintah (Studi Kasus Pada Satuan Kerja Pemerintah Daerah Kabupaten Deli Serdang). Skripsi. Program S-1 Departemen Akuntansi Fakultas Ekonomi dan Bisnis Universitas Sumatera Utara. Medan.

Deegan, C., M. Rankin, dan J. Tobin. 2002. An Examination of the Corporate Social and Environmental Disclosure of BHP from 1983-1997: A Test of Legitimacy Theory. Accounting, Auditing, $\mathcal{E}$ Accountability Journal 15(3): 312-343.

Endrayani, K. S., I. M. P. Adiputra, dan N. A. S. Darmawan. 2014. Pengaruh Penerapan Anggaran Berbasis Kinerja terhadap Akuntabilitas Kinerja Instansi Pemerintah (Studi Kasus pada Dinas Kehutanan UPT KPH Bali Tengah Kota Singaraja). E-Jurnal Akuntansi Universitas Pendidikan Ganesha 2(1).

Ghozali, I. 2013. Aplikasi Analisis Multivariate dengan Program IBM SPSS 21 Update PLS Regresi. Edisi Ketujuh. Badan Penerbit Universitas Diponegoro. Semarang.

Grossi, G., E. Mori, dan F. Bardelli. 2014. From Consolidation to Segment Reporting in Local Government: Accountability Needs, Accounting Standards, and the Effect on Decision-Makers. Journal of
Modern Accounting and Auditing 10(1): 32-46.

Halim, A. dan S. Abdullah. 2006. Hubungan dan Masalah Keagenan di Pemerintah Daerah: (Sebuah Peluang Penelitian Anggaran dan Akuntansi). Jurnal Akuntansi Pemerintah 2(1): 53-64.

Haspiarti. 2012. Pengaruh Penerapan Anggaran Berbasis Kinerja terhadap Akuntabilitas Kinerja Instansi Pemerintah (Studi Pada Pemerintah Kota Pare-Pare). Skripsi. Fakultas Ekonomi dan Bisnis, Universitas Hasanuddin. Makassar.

Herawaty, N. 2011. Pengaruh Kejelasan Sasaran Anggaran, Pengendalian Akuntansi dan Sistem Pelaporan terhadap AKIP Daerah Kota Jambi. Simposium Nasional Akuntansi XIII Jambi.

Hidayatullah, A. dan Heridjiono, I. 2015. Pengaruh Kejelasan Sasaran Anggaran, Pengendalian Akuntansi, Sistem Pelaporan terhadap Akuntabilitas Kinerja SKPD di Merauke. Prosiding Seminar Nasional Multi Disiplin Ilmu dan Call for Papers Unisbank.

Nuraini dan D. Indudewi. 2012. Pengaruh Kejelasan Sasaran Anggaran, Pengendalian Akuntansi, dan Sistem Pelaporan terhadap Akuntabilitas Kinerja Instansi Pemerintah Kabupaten Brebes. Jurnal SOLUSI 11(4): 63-77.

Jensen, M. C. dan W. H. Meckling. 1976. Theory of the Firm: Managerial Behavior, Agency Costs and Ownership Structure. Journal of Financial Economics 3(4): 305-360.

Kenis, I. 1979. Effects on Budgetary Goal Characteristics on Managerial Attitudes and Performance. The Accounting Review 54(4): 707-721.

Kewo, C. L. 2014. The Effect of Participative Budgeting, Budget Goal Clarity and Internal Control Implementation on Managerial Performance. Research Journal of Finance and Accounting 5(12): 81-87.

Kloot, L. 2009. Performance Measurement and Accountability in an Australian Fire Service. International Journal of Public Sector Management 22(2): 128-145. 
Kusumaningrum, I. 2010. Pengaruh Kejelasan Sasaran Anggaran, Pengendalian Akuntansi, dan Sistem Pelaporan terhadap Akuntabilitas Kinerja Instansi Pemerintah Provinsi Jawa Tengah. Tesis. Prodi Magister Akuntansi Program Pasca Sarjana Universitas Diponegoro. Semarang.

Kuraesin RS, A. 2014. Effect of the Effectiveness and Performance-Based Development Budget Commitment to the Organization Managerial Performance (Research at the City of Bandung Indonesia). International Journal of Business, Economics and Law 4(1): 71-81.

Mardiasmo. 2002. Akuntansi Sektor Publik. Penerbit Andi. Yogyakarta.

Mediawati, E. dan K. Kurniawan. 2012. Pengaruh Penganggaran Berbasis Kinerja terhadap Akuntabilitas Kinerja Instansi Pemerintah Daerah di Wilayah IV Priangan. Prosiding Seminar Nasional, Forum Bisnis dan Keuangan 1. Universitas Pendidikan Indonesia.

Putra, D. 2013. Pengaruh Akuntabilitas Publik dan Kejelasan Sasaran Anggaran Terhadap Kinerja Manajerial Satuan Perangkat Daerah Kota Padang. Jurnal Akuntansi 1(1): 1-23.

Peraturan Presiden Nomor 29 tahun 2014 tentang Sistem Akuntabilitas Kinerja Instansi Pemerintah.

Peraturan Menteri Dalam Negeri Nomor 13 tahun 2006 tentang Pedoman Pengelolaan Keuangan Daerah.

Peraturan Pemerintah Nomor 58 tahun 2005 tentang Pengelolaan Keuangan Daerah.

60 tahun 2008 ten tang Sistem Pengendalian Internal Pemerintah.

Primayani, P. R., N. T. Herawati, dan N. A. S. Darmawan. 2014. Pengaruh Pengendalian Internal, Value for Money, Penyajian Laporan Keuangan dan Aksesibilitas Laporan Keuangan terhadap Akuntabilitas Pengelolaan Keuangan (Studi Empiris pada SKPD di Pemerintahan Daerah Kabupaten Klungkung). E-Journal S1 Akuntansi Universitas Pendidikan Ganesha 2(1).
Primayoni, N. K. R., I. M. P. Adiputra, dan E. Sujana. 2014. Pengaruh Kejelasan Sasaran Anggaran dan Efektivitas Pengendalian Internal terhadap Akuntabilitas Kinerja Instansi Pemerintah (Studi Kasus pada SKPD Kabupaten Klungkung). E-Journal S1 Akuntansi Universitas Pendidikan Ganesha 2(1).

Rahmat, I. S. B. 2014. Pengaruh Pengendalian Intern dan Audit Kinerja terhadap Akuntabilitas Publik (Studi Kasus pada Pemerintah Kota Bandung). Skripsi. Universitas Komputer Indonesia. Bandung.

Setiawan, E. 2013. Pengaruh Kejelasan Sasaran Anggaran, Pengendalian Akuntansi dan Sistem Pelaporan terhadap Akuntabilitas Kinerja Pemerintah. Jurnal Online Mahasiswa (JOM) Universitas Riau 1(1): 1-14.

Sugiyono. 2013. Statistika Untuk Penelitian. CV Alfabeta. Bandung.

Suhartono, E. dan M. Solichin. 2006. Pengaruh Kejelasan Sasaran Anggaran terhadap Senjangan Anggaran Instansi Pemerintah Daerah dengan Komitmen Organisasi sebagai Pemoderasi. Simposium Nasional Akuntansi IX Padang.

Suriani, S. 2015. The Effect of PerformanceBased Budgeting Implementation towards the Institution Performance Accountability (Case Study: Wajo). Information Management and Business Review (IMBR) 7(4): 6-22.

Wibisono, S., dan Riharjo, I. B. 2016. Pengaruh Penerapan Anggaran Berbasis Kinerja Terhadap Akuntabilitas Kinerja Instansi Pemerintah. Jurnal Ilmu dan Riset Akuntansi (JIRA) 6(9): 111-133.

Yani, F. 2014. Pengaruh APBD Berbasis Kinerja dan Pengawasan DPRD terhadap Akuntabilitas Kinerja Instansi Pemerintah (Studi Empiris pada Instansi Pemerintah Daerah di Kota Padang). Jurnal Akuntansi 1(2).

Yee, C. M., E. W. S. Khin, dan K. Ismail. 2016. An Analysis of Budgetary Goals Impacting Organizational Performance. Audit Financiar 14(137): 551-563. 
Yulianti, R., Hardi, dan H. Rusli. 2014. Pengaruh Kejelasan Sasaran Anggaran, Kesulitan Sasaran Anggaran, Pengendalian Akuntansi dan Sistem Pelaporan terhadap Akuntabilitas Kinerja Instansi Pemerintah (Studi pada Satuan Kinerja Perangkat Daerah Kabupaten Pelalawan). Jurnal Online Mahasiswa (JOM) 1(2): 1-15.
Zakiyudin, M. A. dan Suyanto. 2015. Kejelasan Sasaran Anggaran, Pengendalian Akuntansi, Sistem Pelaporan dan Akuntabilitas Kinerja Instansi Pemerintah pada Inspektorat Jenderal Kementerian Agama RI. Jurnal Riset Akuntansi dan Perpajakan (JRAP) 2(1): 89-96. 